\title{
Correction to: Why do students skip classroom lectures: A single dental school report
}

Waleed A. Alamoudi', Azza F. Alhelo', Soulafa A. Almazrooa', Osama M. Felemban², Nada O. Binmadi', Nada A. Alhindi', Sarah A. Ali ${ }^{1}$, Sara K. Akeel ${ }^{1}$, Sana A. Alhamed ${ }^{1}$, Ghadah M. Mansour ${ }^{1}$ and Hani H. Mawardi ${ }^{{ }^{*}}$

\section{Correction to: BMC Medical Education 21, 388 (2021)}

https://doi.org/10.1186/s12909-021-02824-3

Following publication of the original article [1], due to a typesetting error, the authors were incorrectly affiliated.

The authors' affiliations have been updated above and the original article [1] has been corrected.

\section{Author details}

'Department of Oral Diagnostic Sciences, King Abdul-Aziz University- Faculty of Dentistry, Jeddah, Saudi Arabia. ${ }^{2}$ Department of Pediatric Dentistry, King Abdulaziz University- Faculty of Dentistry, Jeddah, Saudi Arabia.

Published online: 12 August 2021

\section{Reference}

1. Alamoudi WA, et al. Why do students skip classroom lectures: a single dental school report. BMC Medical Education. 2021;21:388. https://doi.org/1 0.1186/s12909-021-02824-3.

The original article can be found online at https://doi.org/10.1186/s12909021-02824-3.

* Correspondence: Hmawardi@kau.edu.sa

'Department of Oral Diagnostic Sciences, King Abdul-Aziz University- Faculty of Dentistry, Jeddah, Saudi Arabia

Full list of author information is available at the end of the article

(c) The Author(s). 2021 Open Access This article is licensed under a Creative Commons Attribution 4.0 International License, which permits use, sharing, adaptation, distribution and reproduction in any medium or format, as long as you give appropriate credit to the original author(s) and the source, provide a link to the Creative Commons licence, and indicate if changes were made. The images or other third party material in this article are included in the article's Creative Commons licence, unless indicated otherwise in a credit line to the material. If material is not included in the article's Creative Commons licence and your intended use is not permitted by statutory regulation or exceeds the permitted use, you will need to obtain permission directly from the copyright holder. To view a copy of this licence, visit http://creativecommons.org/licenses/by/4.0/ The Creative Commons Public Domain Dedication waiver (http://creativecommons.org/publicdomain/zero/1.0/) applies to the data made available in this article, unless otherwise stated in a credit line to the data. 